\title{
Orchids of Suspa-Kshamawoti, Dolakha -An annotated checklist
}

\begin{abstract}
S. Karki ${ }^{1 *}$ and S. K. Ghimire ${ }^{1}$
Suspa-Kshamawoti area of Dolakha district covers diverse vegetation types and harbors many interesting species of orchids. This paper documents 69 species of orchids covering 33 genera based on repeated field surveys and herbarium collections. Of them, 50 species are epiphytic (including lithophytes) and 19 species are terrestrial. Information regarding habit and habitat, phenology, host species and elevational range of distribution of each species are provided in the checklist.
\end{abstract}

\section{Keywords : Bulbophyllum, Nepal, Orchidaceae}

$\mathrm{O}$ rchids are one of the most diverse and highly evolved groups of flowering plants, and orchidaceae is the largest family comprising 29,199 species and are globally distributed (Govaerts et al., 2017). Out of them, two-third belong to epiphytes (Zotz and Winkler, 2013). In Nepal, orchidaceae is one of the major families amongst the higher flowering plants and comprises 502 taxa belonging to 108 genera, which forms around 8 percent of our flora (Raskoti and Ale, 2019). The number of species might increase because many areas of Nepal are yet to be explored. With various growth forms, orchids are distributed from $62 \mathrm{~m}$ to $5,200 \mathrm{~m}$, growing in various types of habitats in Nepal (Rokaya et al., 2013).

Due to their beautiful long-lasting flowers and the presence of important chemicals, orchids are harvested, grown and traded for various purposes as ornamental plants, medicinal products and food (Hinsley et al., 2017). Although with great diversity and prodigious economic and ecological values, orchids are also threatened by habitat destruction and fragmentation, unsustainable harvesting and illegal trade in Nepal. These activities are pushing many orchids into small populations in the wild and finally towards extinction.

Research on orchids has been carried out by several researchers in Nepal. Some notable contributions on documentation of orchid flora are made by Bajracharya (2001; 2004); Rajbhandari and Bhattrai (2001); Bajracharya and Shrestha (2003); Rajbhandari and Dahal (2004); Milleville and Shrestha (2004); Subedi et al. (2011); Rajbhandari (2015); Raskoti (2015); Raskoti and Ale $(2009 ; 2011 ; 2012 ; 2019)$ and Bhandari et al. (2016 b; 2019). Suspa-Kshamawoti, the northern part of the Dolakha district covers diverse vegetation and harbors some interesting species of orchids. Bhandari et al. (2016a) reported the endemic orchid Panisea panchasensis Subedi., from the same area with a very good population than in its type locality Panchase, Kaski, Nepal. However, no comprehensive record of orchid flora of this region is available till date. Thus, this research is aimed to document the orchid flora of Suspa-Kshamawoti area, the region outside the protected area. This work also highlights the importance of forest outside the protected area in maintaining orchid diversity.

\section{Study area}

The study area Suspa-Kshamawoti (now Bhimeshor Municipality-1), lies in the northern part of the Dolakha District $\left(27^{\circ} 42^{\prime} 38\right.$. 82" N and $86^{\circ} 02^{\prime} 21$. $88^{\prime \prime}$ E) (Figure 1). The elevation ranges from 1,603 $\mathrm{m}$ to around 2,600 $\mathrm{m}$ above mean sea level (amsl). The area, moreover, exhibits sub-tropical to lower temperate climate; therefore, experiences high rainfall during the monsoon period. Floristically,

1 Central Department of Botany, Tribhuvan University, Kirtipur, Kathmandu, Nepal. *E-mail : karki.sangram99@gmail.com 
the area is categorized into four forest types, viz. Schima-Castanopsis and Alnus nepalensis forest in the lower belt, and Daphniphyllum-Symplocos and Quercus semecarpifolia forest in the upper belt. Although the study area covers the narrow elevational gradient, it represents the diverse forest patches of older and major host tree species, such as Alnus nepalensis, Schima wallichii, Daphniphyllum himalense, Lyonia ovalifolia, Castanopsis indica and Eurya acuminata. These host trees support many interesting epiphytic orchids on their tree canopies.

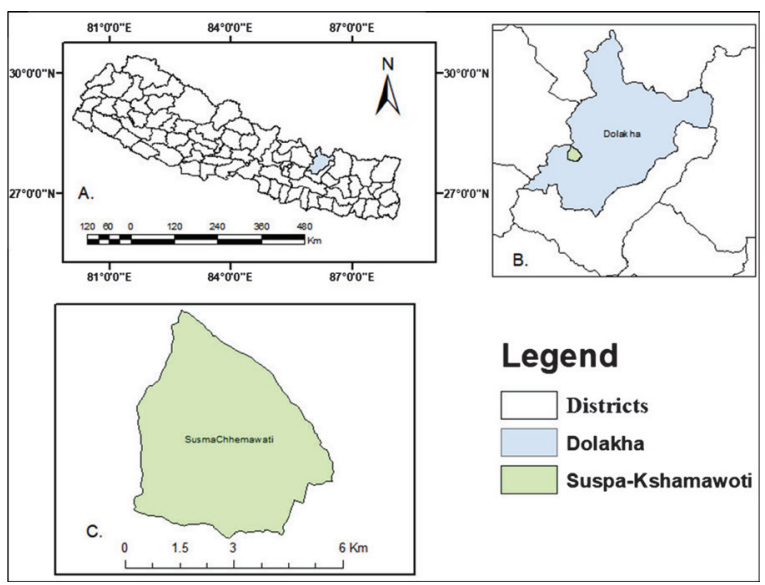

Figure 1. Location of the study area in Nepal A. Nepal, B. Dolakha district and C. SuspaKshamawoti (Study area)

\section{Materials and methods}

The present study is the result of extensive field surveys covering all the seasons during 2015-2019 $\mathrm{AD}$ in different localities of the Suspa-Kshamawoti region, the elevation of which ranges from 1,603 m to 2,500 $\mathrm{m}$ amsl. Different community forests were surveyed during the trips. All the orchid species encountered were recorded along with their voucher specimens adopting the standard technique of Jain and Rao (1977). In the case of epiphytic orchids, their host species were also noted. Photographs of each orchid and their host species (in case of epiphytes) were taken. The identification of species was done by adopting the methods of White and Sharma (2000); Rajbhandari and Bhattrai (2001); Raskoti and Ale (2009); Rajbhandari (2015), and Rajbhandariand Rai(2017). Roscov et al.(2019) was followed for the nomenclature and author citation of the genus and species. The collected specimens were deposited at the Tribhuvan University Central Herbarium (TUCH).

\section{Results}

This research enumerated 69 species of orchids belonging to 33 genera from the SuspaKshamawoti area (Appendix 1). The present study also reported 18 host species of 50 epiphytic orchids. Global distribution, distinguishing character, habit, phenology of flowering and their host species (in case of epiphytes) are also provided. Some photographs of epiphytic orchids are presented in Figure 2 and Figure 3 while the terrestrial orchids are provided in Figure 4.

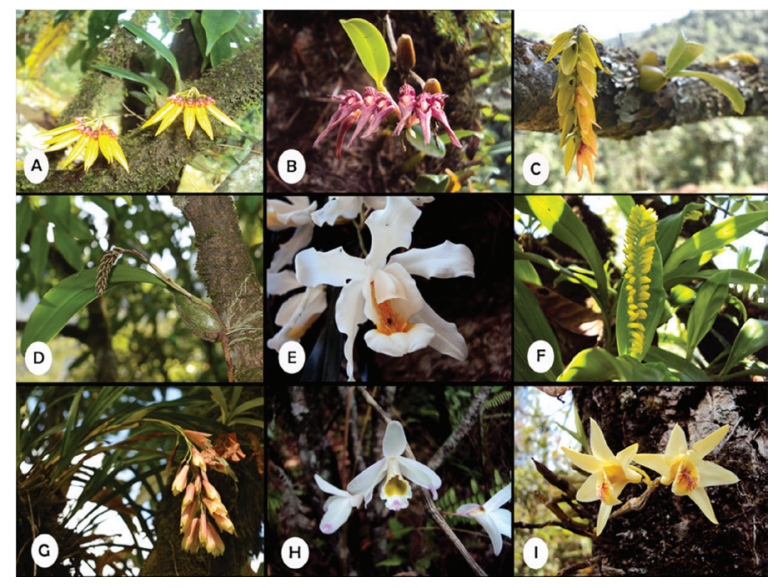

Figure 2 : (A) Bulbophyllum retusiusculum, (B) B. yoksunense, (C) B. viridiflorum, (D) B. careyanum, (E) Coelogyne cristata, (F) Cryptochilus luteus, (G) Cymbidium elegans, (H) Dendrobium amoenum and (I) D. heterocarpum

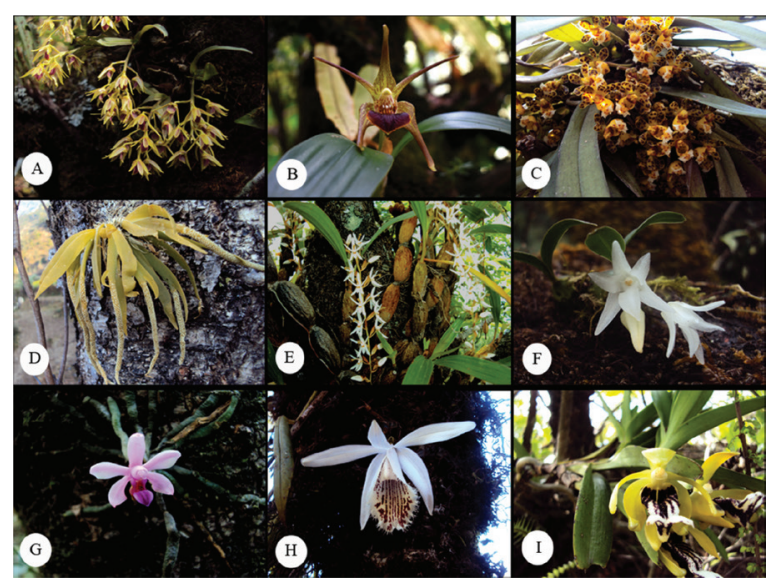

Figure 3. (A) Dendrobium porphyrochilum, (B) D. amplum, (C) Gastrochilus calceolaris, (D) Oberonia pachyrachis, (E) Otochilus porrectus, (F) Panisea panchaseensis, (G) Phalaenopsis taenialis, (H) Pleione humilis and (I) Vanda cristata 


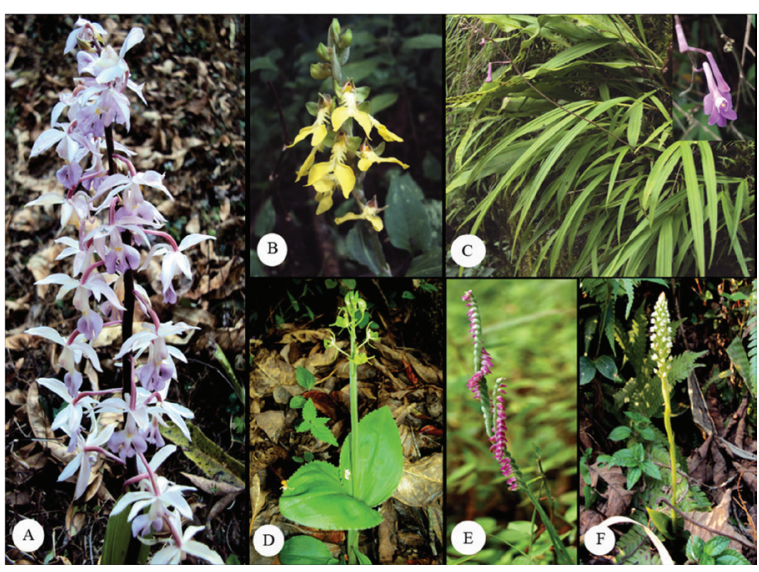

Figure 4. (A) Calanthe plantaginea, (B) Odontochilus lanceolatus, (C) Anthogonium gracile, (D) Liparis cathcartii, (E) Spiranthes sinensis and (F) Goodyera procera

\section{Discussion}

The present study recorded 69 orchid species belonging to 33 genera from the SuspaKshamawoti region, Dolakha district. Of these, 50 species are epiphytic and 19 species are terrestrial. This shows the dominance of epiphytic orchids in the study area where there is the presence of most preferable host trees, like S. wallichii, A. nepalensis, Rhododendron arboreum and D. himalense. Orchid species, such as Uncifera acuminata, Porpax elwesi, D. amoenum, Rhynchostylis retusa, $B$. careyanum, $D$. moniliforme, Luisia tristis, and D. amplum were found to be very rare in the study area, whereas B. reptans, D. heterocarpum, Vanda cristata, $G$. calceolaris, Eria coronaria, Liparis resupinata, Oberonia pachyrachis and Oberonia falcata were commonly noticed. Out of the 33 genera present, Bulbophyllum was found to be the largest one comprising 11 species followed by Dendrobium with 7 species. Epiphytic orchids were mostly recorded on the host trees, like $S$. wallichii, $D$. himalense and A. nepalensis, the most preferred host species of epiphytic orchids.

It showed that the forests outside the protected area have also supported for many rare and endangered species of orchids to thrive well. Therefore, it is important to save the patches of the forest outside the protected area as they function as habitat islands, which have continuously maintained the population of many endangered orchid species. Thus, it is recommended that future conservation plans should focus on the conservation of forests outside the protected area for long-term conservation of orchid resources.

\section{Conclusion}

The environmental and climatic condition of the Suspa-Kshamawoti area is suitable for various epiphytic and terrestrial species of orchids. The moist deciduous forest floor has supported many terrestrial species whereas the large trees with fissured bark covered with moss have supported many epiphytic orchid species to flourish. The destruction of habitats due to deforestation and construction activities have resulted in drastic depletion of orchid species in the study area. The selective logging of trees, such as Schima wallichii, A. nepalensis, $R$. arboreum, and $D$. himalense has increased for timber extraction. This has severely reduced the number of epiphytic orchids in the study area. Therefore, it is necessary to conserve habitats and the most preferable host species in order to conserve many orchid species in the wild.

\section{Acknowledgements}

We are grateful to the Head, Central Department of Botany for providing necessary laboratory facilities. We are also thankful to Prabin Bhandari for the valuable suggestions during our fieldwork. We would also like to thank the local people for their support during our fieldwork.

\section{References}

Bhandari, P., Karki, S. and Budhamagar, S. 2016a. A new locality record for endemic Panisea panchaseensis Subedi (Orchidaceous) in Nepal. Pleione 10 (1) : 183-185.

Bhandari, P., Shakya, L. R. and Shrestha, K. K. 2016b. Zeuxine membranacea (Orchidaceae) : An addition to the orchid flora of Nepal. The Journal of Japanese Botany 91 : 317-320.

Bhandari, P., Shakya, L. R. and Chaudhary, R. P. 2019. Zeuxine lindleyana (Orchidaceae) : An addition to the orchid flora of Nepal. The Journal of Japanese Botany 94 : 4546. 
Bajracharya, D. M. 2001. Eria apertiflora Summerh. and E. bipunctata Lindl. (Orchidaceae), new records for the Nepal Himalaya. The Journal of Japanese Botany 76 : 297-302.

Bajracharya, D. M. 2004. The genus Eria Lindley (Orchidaceae) in the Himalayas : A taxonomic revision. Ph. D. Thesis, Tribhuvan University, Nepal.

Bajracharya, D. M. and Shrestha, K. K. 2003. Eria nepalensis (Orchidaceae), a new species from Nepal. The Journal of Japanese Botany 78 (3) : 158-161.

Chen, X., Liu Z., Zhu, G., Lang, K., Ji, Z., Luo, Y., Jin, X., Cribb, P. J., Wood, J. J., Gale, S. W., Ormerod, P., Vermeulen, J. J., Wood, H. P., Clayton, D. and Bell, A. 2009. Orchidaceae. In Flora of China, vol. 25. (eds)Wu Z., Raven P. H. \& Hong D. Science Press, Beijing; Missouri Botanical Garden Press, St. Louis, USA.

Govaerts, R., Bernet, P., Kratochvil, K., Gerlach, G., Carr, G., Alrich, P., Pridgeon, A. M., Pfahl, J., Campacci, MA., Holl and Baptista, D., Tigges, H., Shaw, J., Cribb, P., George, A., Kreuz, K. and Wood, J. J. 2017. World Checklist of Orchidaceae. Kew : Facilitated by the Royal Botanic Gardens. http : //apps. kew. org/wcsp/ (accessed 23 March, 2017).

Hinsley, A., de Boer, H. J., Fay, M. F., Gale, S. W., Gardiner, L. M., Gunasekara, R. S., Kumar, P., Masters, S., Metusala, D., Roberts, D. L. and Veldman, S. 2017. A review of the trade in orchids and its implications for conservation. Botanical Journal of the Linnean Society 186 (4) : 435-455.

Jain, S. K. and Rao, R. R. 1977. A Hand Book of Field \& Herbarium Methods. Today \& Tomorrow's Printers \& Publishers, New Delhi.

Milleville, R., and Shrestha, T. B. 2004. Nepal Orchids in Pictures. Malla Prakashan, Kathmandu, Nepal.
Rajbhandari, K. R. and Bhattarai, S. 2001. Beautiful Orchids of Nepal. Keshab R. Rajbhandari, Kathmandu, Nepal.

Rajbhandari, K. R. and Dahal, S. 2004. Orchids of Nepal : a checklist. Botanica Orientalis 4 : 89-106.

Rajbhandari, K. R. 2015. A H and book of the Orchids of Nepal. Department of Plant Resources, Thapathali, Kathmandu,Nepal.

Rajbhandari, K. R. and Rai, S. K. 2017. A H and book of Flowering Plant of Nepal, Volume-1. Department of Plant Resources, Thapathali, Kathmandu, Nepal.

Raskoti, B. B. 2009. The Orchids of Nepal. Published by B. B. Raskoti and R. Ale, Kathmandu, Nepal.

Raskoti, B. B. and Ale, R. 2011. A species of Sunipia (Orchidaceae) from Nepal. Phytotaxa 31 : 55-58.

Raskoti, B. B. and Ale, R. 2012. Liparisferruginea Lindley (Orchidaceae) : A new record for the flora of Nepal. Taiwania 57 : 308-311.

Raskoti, B. B. and Kurzweil, H., 2015. Odontochilusn and ae (Orchidaceae; Cranichideae; Goodyerinae) : A new species from Nepal. Phytotaxa 233 (3) : 293-297.

Raskoti, B. B. 2015. A new species of Gastrochilus and new records for the orchids of Nepal. Phytotaxa 233 (2) : 179-184.

Raskoti, B. B. and Ale, R. 2019. New species of orchids and notes on Orchidaceae of Nepal. Phytotaxa 394 (4) : 257-266.

Rokaya, M. B., Raskoti, B. B., Timsina, B. and Muenzbergova, Z. 2013. An annotated checklist of the orchids of Nepal. Nordic Journal of Botany 31 : 511-550. 
Roskov, Y., Ower, G., Orrell, T., Nicolson, D., Bailly, N., Kirk, P. M., Bourgoin, T., DeWalt, R. E., Decock, W., Nieukerken, E. van, Zarucchi J. and Penev L., eds. (2019). Species 2000 \& ITIS Catalogue of Life, 2019 Annual Checklist. Digital resource at www.catalogueoflife.org/annualchecklist/2019. Species 2000 : Naturalis, Leiden, the Netherlands. ISSN 2405-884X.

Subedi, A., Chaudhary, R. P., Vermeulen, J. J. and Gravendeel, B. 2011. Panisea panchaseensis sp. nov. (Orchidaceae) from central Nepal. Nordic Journal of Botany 29 (3) : 361-365.
White, C. and Sharma, B. 2000. Wild orchids of Nepal : A guide in the Himalayan Orchids of Tribhuvan Rajpath and Chitwan Jungle. White Lotus Press, Bangkok, Thailand.

Zotz, G. and Winkler, U. 2013. Aerial roots of epiphytic orchids : the velamen radicum and its role in water and nutrient uptake. Oecologia 171 (3) : 733-741. 


\section{Appendix 1. Orchid checklist}

AGROSTROPHYLLUM Bl.

About 60 species distributed in the Old World tropics from Seychelles and tropical Asia east to the Pacific Island, New Guinea as the center of distribution (Chen et al., 2009); 2 species in Nepal (Rajbhandari and Rai, 2017), 1 species in Suspa-Kshamawoti.

Agrostophyllum callosum Rchb. f. in Seem., Fl. Vit. : 296 (1868).

Habit : Epiphyte, flowers pinkish white.

Flowering : May-Aug. Exsiccatae : Karki S. 005 (TUCH)

Altitude : 1,820 m

Habitat : Epiphyte in mixed deciduous forest and humid evergreen forest

Host species : Schima wallichii, Daphniphyllum himalense and Lyonia ovalifolia

ANTHOGONIUM Wall. ex Lindl.

Only one species distributed in Bangladesh, Bhutan, Cambodia, China, N India, Laos, Myanmar, Nepal, Sri Lanka, Thailand, Vietnam (Chen et al., 2009); 1 species in Nepal (Rajbhandari and Rai, 2017), 1 species in SuspaKshamawoti.

Anthogonium gracile Wall. ex Lindl., Gen. Sp. Orchid. Pl. : 426 (1840). Fig. 4C

Anthogonium corydaloides Schltr.

Habit : Terrestrial, flowers pink to white.

Flowering : Aug-Nov. Exsiccatae : Karki S. 006 (TUCH)

Altitude : 1,620-1,780 m

Habitat : Terrestrial growing on grassy slopes and rock

BULBOPHYLLUM Thouars.

About 1,900 species distributed in tropical areas of both Old and New Worlds (Chen et al., 2009); 36 species in Nepal (Rajbhandari and Rai, 2017; Raskoti and Ale, 2019), 11 species in SuspaKshamawoti.

Bulbophyllum affine Wall. ex Lindl. Gen. Sp. Orchid Pl. : 48 (1830).

Bulbophyllum kusukusense Hayata

Habit : Epiphyte, flowers white with pink-lined, solitary.

Flowering : May-Aug. Exsiccatae : Karki S. 007 (TUCH)

Altitude : $1723 \mathrm{~m}$

Habitat : Epiphyte in mixed deciduous forest

Host species : Schima wallichii and Lyonia ovalifolia

Bulbophyllum careyanum (Hook. ) Spreng.,
Syst. Veg. ed. 16 (3) : 732 (1826). Fig. 2D

Anisopetalon careyanum Hook.

Phylloorchis purpurea (D. Don) Kuntze.

Habit : Epiphyte, flowers purplish-brown, 0. 5-0. $8 \mathrm{~cm}$ long.

Flowering : Sep-Dec. Exsiccatae : Karki S. 008 (TUCH)

Altitude : 1,604 m

Habitat : Epiphyte in dense humid evergreen forest

Host species : Schima wallichii

Bulbophyllum cylindraceum Wall. ex Lindl., Gen. Sp. Orchid. Pl. : 53 (1830).

Bulbophyllum imbricatum Griff.

Habit : Epiphyte, flowers many, pale purple.

Flowering : Oct-Nov. Exsiccatae : Karki S. 009 (TUCH)

Altitude : $1,740-2,400 \mathrm{~m}$

Habitat : Epiphyte in dense humid evergreen forest or lithophytic on moist rocks

Host species : Daphniphyllum himalense and Schima wallichii

Bulbophyllum hirtum (Sm. ) Lindl. ex Wall., Gen. Sp. Orchid. Pl. : 51 (1830).

Stelis hirta $\mathrm{Sm}$.

Habit : Epiphyte or lithophytes, flowers greenish white, highly scented.

Flowering : Oct-Nov. Exsiccatae : Karki S. 0010

(TUCH)

Altitude : $1,740-2,400 \mathrm{~m}$

Habitat : Epiphyte in dense humid evergreen forest or lithophytic on moist rocks

Host species : Buddleja asiatica and Schima wallichii

Bulbophyllum leopardinum (Wall. ) Lindl. ex Wall., Gen. Sp. Orchid. Pl. : 48 (1830).

Dendrobium leopardinum Wall.

Habit : Epiphyte or lithophytes, flowers creamy yellow to pale green, spotted with red dots, lip yellow.

Flowering : May-Aug. Exsiccatae : Karki S. 0011 (TUCH)

Altitude : $1,740-1,800 \mathrm{~m}$

Habitat : Epiphyte on tree trunks or lithophytic on rocks

Host species : Schima wallichii, Engelhardia spicata

Bulbophyllum purpureofuscum J. J. Verm., Schuit. \& de Vogel., Phytotaxa 166 (2) : 105 (2014).

Sunipia cirrhata (Lindl. ) P. F. Hunt. 
Bulbophyllum cirrhatum (Lindl. ) Hook. f.

Habit : Epiphyte, white purple veins, 4-8 flowered, lip purple.

Flowering : Oct-Dec. Exsiccatae : Karki S. 0012 (TUCH)

Altitude : 1,800-2,215 m

Habitat : Epiphyte on tree trunks

Host species : Schima wallichii

Bulbophyllum reptans (Lindl. ) Lindl. ex Wall., Numer. List : n. 1988 (1829).

Tribrachia reptans Lindl.

Habit : Epiphyte, flowers 3-6, pale yellow with purplish-red stripes.

Flowering : Jan-Mar. Exsiccatae : Karki S. 0013 (TUCH)

Altitude : 1,930-2,400 m

Habitat : Epiphyte on evergreen forest or lithophytic on rocks

Host species : Schima wallichii, Daphniphyllum himalense and Symplocos sp.

Bulbophyllum retusiusculum Rchb. f., Gard. Chron. 1869 : 1182 (1869). Fig. 2A

Cirrhopetalum retusiusculum (Rchb. f. ) Hemsley, Gard.

Habit : Epiphyte, flowers yellow with reddish veins.

Flowering : Sep-Dec. Exsiccatae : Karki S. 0014 (TUCH)

Altitude : 2,400 m

Habitat : Epiphyte on tree trunks

Host species : Rhododendron arboreum

Bulbophyllum roseopictumJ. J. Verm., Schuit. \& de Vogel (2014).

Sunipia bicolor Lindl.

Habit : Epiphyte, flowers small, whitish with purplish-red stripes, lip purple-red.

Flowering : Jul-Nov. Exsiccatae : Karki S. 0015 (TUCH)

Altitude : 2,000-2,400 m

Habitat : Epiphyte on tree trunks

Host species : Schima wallichii and Daphniphyllum himalense

Bulbophyllum viridiflorum (Hook. f. ) Schltr., Orchis 4 : 108 (1910). Fig. 2C

Cirrhopetalum viridiflorum Hook. f.

Habit : Epiphyte, flowers 5-12, yellow.

Flowering : Oct-Nov. Exsiccatae : Karki S. 0016 (TUCH)

Altitude : 2,300 m

Habitat : Epiphyte on tree trunks

Host species : Daphniphyllum himalense

Bulbophyllum yoksunense J. J. Sm. Bull. Jard. Buitenzorg 28 : 29 (1912). Fig. 2B
Cirrhopetalum brevipes Hook. f.

Habit : Epiphyte, flowers 6-12, creamy white with pink stripes.

Flowering : Sep-Nov. Exsiccatae : Karki S. 0017 (TUCH)

Altitude : 2,000-2,210 m

Habitat : Epiphyte on subtropical mixed forest

Host species : Daphniphyllum himalense and Symplocos ramosissima

CALANTHE R. Brown

About 150 species distributed in tropical and subtropical Asia, Australia, New Guinea, SW Pacific Islands, as well as tropical Africa and Central and NW South America (Chen et al., 2009); 16 species in Nepal (Rajbhandari and Rai, 2017; Raskoti and Ale, 2019), 4 species in SuspaKshamawoti.

Calanthe brevicornu Lindl., Gen. Sp. Orchid P1. : 251 (1833).

Alismorkis brevicornu (Lindl. )

Habit : Terrestrial, flowers laxy, 5-13 in number, yellowish-green with pinkish-red strations.

Flowering : May-Jun. Exsiccatae : Karki S. DO 1 (TUCH)

Altitude : 1,800-2,200 m

Habitat : Terrestrial in the dense forest floor

Calanthe mannii Hook. f., Fl. Brit. Ind. 5 : 850 (1890).

Calanthe brachychila Gagnep.

Habit : Terrestrial, flowers dark brown, lip golden yellow.

Flowering : May-Jun. Exsiccatae : Karki S. DO 2 (TUCH)

Altitude : 1,800-2,200 m

Habitat : Terrestrial in the dense forest floor

Calanthe plantaginea Lindl., Gen. Sp. Orchid P1. 250 (1833). Fig. 4A

Alismorkis lindleyana Kuntze

Habit : Terrestrial, flowers 12-25 or more, pinkish to white, scented.

Flowering : Mar-Apr. Exsiccatae : Karki S. DO 3 (TUCH)

Altitude : 1,950-2,200 m

Habitat : Terrestrial in the evergreen broad leaved forest floor

Calanthe trulliformis King \& Pantl., J. Asiat. Soc. Bengal 64 (2) : 337 (1895).

Habit : Terrestrial, flowers chocolate brown, lip white, trowel-shaped.

Flowering : Jul. Exsiccatae : Karki S. DO 4 (TUCH)

Altitude : 1,800-2,200 m

Habitat : Terrestrial in the dense and humus-rich 
forest floor

COELOGYNE Lindl.

About 200 species distributed in tropical and subtropical Asia to Oceania (Chen et al., 2009); 11 species in Nepal (Rajbhandari and Rai, 2017), 4 species in Suspa-Kshamawoti.

Coelogyne corymbosa Lindl., Fol. Orchid., Coelogyne 5 : 7 (1854).

Pleione corymbosa (Lindl. )

Habit : Epiphyte, flowers white, lip with four yellow eyelike spots surrounded by red reddishorange, lip 3 lobed.

Flowering : May-Jun. Exsiccatae : Karki S. 0018 (TUCH)

Altitude : 2,000-2,300 m

Habitat : Epiphyte on tree trunks of evergreen forest

Host species : Schima wallichii, Juglans regia and Daphniphyllum himalense

Coelogyne cristata Lindl., Collect. Bol. : sub t. 33

(1824). Fig. 2E

Cymbidium speciosissimum D. Don

Habit : Epiphyte or lithophytes, flowers white, lip 3 lobed, callus having 5 fimbriate lamellae.

Flowering : Feb-May. Exsiccatae : Karki S. 0019 (TUCH)

Altitude : 1,700-2,110 m

Habitat : Epiphyte or lithophytes on tree trunks or exposed rocks

Host species : Schima wallichii, Castanopsis indica and Daphniphyllum himalense

Coelogyne fuscescens Lindl., Gen. Sp. Orchid. P1. 41 (1830).

Coelogyne fuscescens var. viridiflorum Pradhan

Habit : Epiphyte, flowers pale brown or ocheryellow, large 2-5 flowered around $4 \mathrm{~cm}$ across, lip pale brown with dark brown spots, 3 lobed.

Flowering : Oct-Dec. Exsiccatae : Karki S. 0020 (TUCH)

Altitude : 1,700-2,110 m

Habitat : Epiphyte on tree trunks

Host species : Schima wallichii, Rhododendron arboreum, Juglans regia

Coelogyne longipes Lindl., Fol. Orchid., Coelogyne 5 : 10 (1854).

Pleione longipes (Lindl. )

Habit : Epiphyte, flowers white to yellow, small 5-7 flowered, lip apex truncate and emarginate, callus with 2 longitudinal lamellae.

Flowering : May-Jun. Exsiccatae : Karki S. $0021(\mathrm{TUCH})$

Altitude : 1,980-2,100 m

Habitat : Epiphyte on tree trunks
Host species : Schima wallichii

CONCHIDIUM Griff.

About 10 species in Bhutan, $\mathrm{S}$ China, N India, S Japan, Laos, Myanmar, Nepal, Thailand, Vietnam (Chen et al., 2009); 3 species in Nepal (Rajbhandari and Rai, 2017; Raskoti and Ale, 2019), 1 species in Suspa-Kshamawoti.

Conchidium muscicola (Lindl. ) Rauschert, Feddes Report. 94 : 444 (1983).

Eria muscicola (Lindl. ) Lindl.

Habit : Epiphyte or lithophytes, flowers small pale green, 2-5 flowered, lip sub-elliptic.

Flowering : Mar-May. Exsiccatae : Karki S. 0022 (TUCH)

Altitude : 1,650-2,100 m

Habitat : Epiphyte on tree trunks or moist rocks

Host species : Schima wallichii

CREPIDIUM Blume.

About 280 species throughout the Asian tropics and sub-tropics, Australasia, Indian Ocean Islands, few species are found in temperate Asia (Chen et al., 2009); 2 species in Nepal (Rajbhandari and Rai, 2017; Raskoti and Ale, 2019), 1 species in Suspa-Kshamawoti.

Crepidium acuminatum (D. Don) Szlach., Fragm. Florist. Geobot. Suppl. 3 : 123 (1995).

Malaxis acuminata D. Don.

Habit : Terrestrial, flowers yellow, pink or purple, small 5-7 flowered, lip apex truncate and emarginate, callus with 2 longitudinal lamellae.

Flowering : May-Jul. Exsiccatae : Karki S. 0023 (TUCH)

Altitude : $1,732 \mathrm{~m}$

Habitat : Terrestrial in dense forest

CRYPTOCHILUS Wall.

About 10 species in Bhutan, $\mathrm{S}$ China, $\mathrm{N}$ India, Laos, Myanmar, Nepal, Thailand, and Vietnam (Chen et al., 2009); 2 species in Nepal (Rajbhandari and Rai, 2017), 1 species in SuspaKshamawoti.

Cryptochilus luteus Lindl., J. Proc. Unn. Soc. Bot. 3 : 21 (1858). Fig. 2F

Cryptochilus ferrari Schltr.

Habit : Epiphyte, flowers campanulate, yellow, many-flowered, petals enclosed in a tube, entire and encallose.

Flowering : Jun-Jul. Exsiccatae : Karki S. 0024

(TUCH)

Altitude : 2,110-2,300 m

Habitat : Epiphyte on tree trunks

Host species : Schima wallichii and Daphniphyllum himalense 


\section{CYMBIDIUM Sw.}

About 55 species distributed in tropical and subtropical Asia, south to Papua New Guinea and Australia (Chen et al., 2009); 9 species in Nepal (Rajbhandari and Rai, 2017), 3 species in SuspaKshamawoti.

Cymbidium elegans Lindl., Gen. Sp. Orchid. P1. 163 (1833). Fig. 2G

Cymbidium longifolium D. Don.

Habit : Epiphyte, flowers cream-yellow to pale yellowish-green, around 18-38 flowered, oblanceolate-triangular.

Flowering : Sep-Oct. Exsiccatae : Karki S. 0025 (TUCH)

Altitude : 1,800-2,300 m

Habitat : Epiphyte on tree trunks

Host species : Schima wallichii, Daphniphyllum himalense

Cymbidium erythraeum Lindl., J. Proc. Linn. Soc. Bot. 3 : 30 (1859).

Habit : Epiphyte, flowers green with heavy reddish-brown longitudinal stripes, flower large 3-8 flowered, lip white with red-brown spots on the mid-lobe.

Flowering : Oct-Dec. Exsiccatae : Karki S. 0026 (TUCH)

Altitude : 2,110-2,300 m

Habitat : Epiphyte on tree trunks

Host species : Schima wallichii and Daphniphyllum himalense

Cymbidium lancifolium Hook., Exot. Fl. 1 : t. 51 (1823)

Cymbidium caulescens Ridl.

Habit : Terrestrial, flowers white to pale green, flower large 2-6 flowered, lip white with purplishbrown markings.

Flowering : May-Aug. Exsiccatae : Karki S. 0027 (TUCH)

Altitude : 1,500-2,400 m

Habitat : Terrestrial in deciduous forest

DENDROBIUM Sw.

Around 1,100 species in India across to Japan, south to Malaysia and Indonesia, east to Australia, New Guinea, and Pacific is lands (Chen et al., 2009); 26 species (Rajbhandari and Rai, 2017), 8 species in Suspa-Kshamawoti.

Dendrobium amoenum Wall. ex Lindl., Gen. Sp. Orchid. Pl. : 78 (1830). Fig. 2H

Dendrobium mesochlorum Lindl.

Habit : Epiphyte, flowers white with pale violet margins, flower many 2-3 cm across, lip white with violet spots on the apex and greenish-yellow on the middle region.
Flowering : May-Jun. Exsiccatae : Karki S. 0028 (TUCH)

Altitude : $1,720-1,900 \mathrm{~m}$

Habitat : Epiphyte on tree trunks

Host species :

Alnus nepalensis, Ficus auriculata, Schima wallichii and Daphniphyllum himalense

Dendrobium amplum Lindl., Gen. Sp. Orchid. Pl. : 74 (1830). Fig. 3B

Epigeneium amplum Lindl.

Habit : Epiphyte, flowers yellowish-green, spotted with deep brown, 1 flowered, lip $\mathrm{p}$ and urate in outline, 3 lobed.

Flowering : Sep-Nov. Exsiccatae : Karki S. 0029

(TUCH)

Altitude : $1,720-2,000 \mathrm{~m}$

Habitat : Epiphyte on tree trunks

Host species : Rhododendron arboreum and Schima wallichii

Dendrobium eriiflorum Griff., Icon. Pl. Asiat. 3

: 316 (1851).

Callista eriiflora (Griff. )

Habit : Epiphyte, flowers greenish-cream, 7-10 flowered, lip curved and spotted with purple stripes.

Flowering : Sep-Oct. Exsiccatae : Karki S. 0030 (TUCH)

Altitude : $1,720-1,900 \mathrm{~m}$

Habitat : Epiphyte on tree trunks

Host species : Alnus nepalensis and Schima wallichii

Dendrobium heterocarpum Wall. ex Lindl., Gen. Sp. Orchid. Pl. : 78 (1830). Fig. 2I

Dendrobium aureum Lindl.

Habit : Epiphyte, flowers silver-white or creamy yellow, usually 10-15 flowered, scented, lip yellow with red stripes.

Flowering : Apr-May. Exsiccatae : Karki S. 0031 (TUCH)

Altitude : 1,720-2,200 m

Habitat : Epiphyte on tree trunks in open forests.

Host species : Alnus nepalensis, Schima wallichii,

Buddleja asiatica and Castanopsis indica

Dendrobium longicornu Lindl. in Edwards's Bot. Reg. 16 : t 1315 (1830).

Dendrobium bulleyi Rolfe.

Habit : Epiphyte, flowers white, usually 1-5 flowered, pendulous, lip veined with yellow or orange, fimbriate.

Flowering : Sep-Nov. Exsiccatae : Karki S. 0032

(TUCH)

Altitude : $1,720-2,400 \mathrm{~m}$

Habitat : Epiphyte on tree trunks in open forests. 
Host species : Lyonia ovalifolia, Schima wallichii, Rhododendron arboreum and Daphniphyllum himalense

Dendrobium moniliforme (L. ) Sw., Nova Acta Regiae Soc. Sci. Upsal. 6 : 85 (1799).

Epidendrum moniliforme L.

Habit : Epiphyte; flowers white, 2-5 or even more in number, lip white tip acute, lip with greenishyellow on the middle region.

Flowering : Sep-Oct. Exsiccatae : Karki S. 0033 (TUCH)

Altitude : 2,300 m

Habitat : Epiphyte on tree trunks

Host species : Schima wallichii and Daphniphyllum himalense

Dendrobium porphyrochilum Lindl., J. Proc. Linn. Soc. Bot. 3 : 18 (1859). Fig. 3A

Dendrobium caespitosum King \&Pantl.

Habit : Epiphyte, flowers pale green with red veins, 10 or even more in number, lip deep purplish-brown.

Flowering : May-Aug. Exsiccatae : Karki S. 0034 (TUCH)

Altitude : 1,800-2,500 m

Habitat : Epiphyte on tree trunks

Host species : Schima wallichii, Viburnum erubescens and Berberis sp.

ERIALindl.

Eria (s. 1. ) comprises around 370 species, widespread in tropical Asia and the whole of the Malay Archipelago, east to New Guinea and Bougainvillea Island(Chen et al. 2009); 14 species in Nepal (Rajbhandari and Rai, 2017; Raskoti and Ale 2019), 1 species in Suspa-Kshamawoti.

Eria coronaria (Lindl. ) Rchb. f. in Walp., Ann. Bot. Syst. 6 : 271 (1861).

Coelogyne coronaria Lindl.

Habit : Epiphyte, flowers white with purple stripes, usually 1-6 in number, large, lip oblong in outline and curved.

Flowering : May-Jun. Exsiccatae : Karki S. 0035 (TUCH)

Altitude : 1,700-2,500 m

Habitat : Epiphyte on tree trunks

Host species : Schima wallichii and Daphniphyllum himalense

GASTROCHILUS D. Don

About 47 species distributed from India and Sri Lanka to East Asia and South to Indonesia (Chen et al., 2009); 7 species in Nepal (Rajbhandari and Rai, 2017), 2 species in Suspa-Kshamawoti.

Gastrochilus calceolaris (Buch. -Ham. ex Sm. )
D. Don, Prodr. F1. Nepal. : 32 (1825). Fig. 3C

Aerides calceolaris Buch. -Ham. Ex Sm. in Rees. Habit : Epiphyte, flowers yellow with purplishbrown markings, lip with white epichile and yellow hypochile.

Flowering : Feb-Apr. Exsiccatae : Karki S. 0036

(TUCH)

Altitude : 1,700-2,300 m

Habitat : Epiphyte on tree trunks

Host species : Schima wallichii and Eurya acuminata

Gastrochilus distichus (Lindl. ) Kuntze, Revis. Gen. P1. 2 : 661 (1891).

Saccolabium distichum Lindl.

Habit : Epiphyte, flowers pale green with reddishbrown spots, 2-4 flowered, lip with saccate hypochile.

Flowering : Jan-May. Exsiccatae : Karki S. 0037 (TUCH)

Altitude : $2,300 \mathrm{~m}$

Habitat : Epiphyte on tree trunks

Host species : Symplocos ramosissima, Eurya acuminata, and Quercus semecarpifolia

GOODYERAR. Br.

About 100 species distributed in S Africa, Asia, NE Australia, Europe, Madagascar, North America including Mexico, SW Pacific Islands (Chen et al., 2009); 11 species in Nepal (Rajbhandari and Rai, 2017; Raskoti and Ale, 2019), 4 species in Suspa-Kshamawoti.

Goodyera biflora (Lindl. ) Hook. f., Fl. Birt. India $6: 114$ (1890).

Georchis biflora Lindl.

Habit : Terrestrial, flowers tubular, creamy white, usually 2 rarely 3 flowered.

Flowering : Feb-Jul. Exsiccatae : Karki S. 0038 (TUCH)

Altitude : 2,200-2,300 m

Habitat : Terrestrial in humus-rich, moist soil Goodyera foliosa (Lindl. ) Benth. ex C. B. Clarke, J. Linn. Soc. Bot. 25 : 73 (1889).

Georchis foliosa Lindl.

Habit : Terrestrial, greenish-white, pubescent.

Flowering : Jul-Sep. Exsiccatae : Karki S. 0039

(TUCH)

Altitude : 2,000-2,100 m

Habitat : Terrestrial in humus-rich, moist soil Goodyera procera (Ker-Gawl. ) Hook., Exot. F1. L : t. 39 (1823). Fig. 4F

Neottia procera Ker-Gawl.

Habit : Terrestrial, flowers white, many (5-20) flowered, lip ovate.

Flowering : Feb-May. Exsiccatae : Karki S. 
0040 (TUCH)

Altitude : 900-2,000 m

Habitat : Terrestrial in humus-rich, moist soil

Goodyera repens (L. ) R. Br.

Satyrium repens L.

Habit : Terrestrial, flowers tubular, creamy white, hairy, many-flowered.

Flowering : Jan-Feb. Exsiccatae : Karki S. 0041 (TUCH)

Altitude : 1,900-2,300 m

Habitat : Terrestrial in humus-rich, moist soil

HABENARIA Willd.

About 600 species distributed worldwide, mainly in tropical and subtropical areas (Chen et al., 2009); 17 species in Nepal (Rajbhandari and Rai, 2017), 1 species in Suspa-Kshamawoti.

Habenaria arietina Hook. f., Fl. Brit. India 6 : 138 (1890).

Ochyrorchis arietina (Hook. f. ) Szlach.

Habit : Terrestrial, flowers white or greenishwhite, many-flowered, petals forming a hood.

Flowering : Jun-Aug. Exsiccatae : Karki S. 0042 (TUCH)

Altitude : 1,400-3,000 m

Habitat : Terrestrial in damp places, sloppy grass lands

HERMINIUM R. Br.

About 25 species distributed in Europe, parts of SW and C Asia, extending to E and SE Asia and the Himalayas (Chen et al., 2009); 24 species in Nepal (Rajbhandari and Rai, 2017), 1 species in Suspa-Kshamawoti.

Herminium lanceum (Thunb. ) Vuijk, Blumea 11 : 228 (1961).

Ophrys lancea Thunb. Ex Sw.

Habit : Terrestrial, flowers pale yellowish to green, many-flowered, petals forming a hood.

Flowering : Jun-Aug. Exsiccatae : Karki S. 0043 (TUCH)

Altitude : 1,700-2,400 m

Habitat : Terrestrial in damp places, sloppy grass lands

LIPARIS L. C. Rich.

About 320 species : tropical Asia, New Guinea, Australia, SW Pacific Islands, subtropical and tropical Americas, Europe and North America (Chen et al., 2009); 18 species in Nepal (Rajbhandari and Rai, 2017; Raskoti and Ale, 2019), 3 species in Suspa-Kshamawoti.

Liparis cathcartii Hook. f. in Hooker, Icon. P1. 19 : t. 1808 (1889). Fig. 4D

Leptorkis cathcartii (Hook. f. ) Kuntze

Habit : Terrestrial, flowers green to purple, more than 10 flowered, lip elliptic-ovate.

Flowering : Jun-Jul. Exsiccatae : Karki S. 0044

(TUCH)

Altitude : 2,200-2,400 m

Habitat : Terrestrial in moist, humus-rich soil

Liparis resupinata Ridl., J. Linn. Soc. Bot. 22 : 290 (1886).

Liparis ridleyi Hook. f.

Habit : Epiphyte, flowers pale green or greenishyellow, 10-50 flowered, lip elliptic-oblong or ovate-oblong.

Flowering : Oct-Dec. Exsiccatae : Karki S. 0045

(TUCH)

Altitude : 1,800-2,500 m

Habitat : Epiphytic on tree trunks

Host species : Daphniphyllum himalense and Eurya acuminata

Liparis viridiflora (Blume) Lindl., Gen. Sp. Orchid. P1. : 31 (1830)

Malaxis viridiflora $\mathrm{B} 1$.

Habit : Epiphyte, flowers pale yellowish-green, lip orbicular or ovate-orbicular.

Flowering : Nov-Feb. Exsiccatae : Karki S. 0046 (TUCH)

Altitude : 1720-1900 m

Habitat : Epiphytic on tree trunks

Host species : Daphniphyllum himalense and Schima wallichii

LUISIA Gaudich.

About 40 species distributed in Bhutan, China, India, Indochina, Indonesia, Japan, Malaysia, New Guinea, Pacific is lands, Philippines, Sri Lanka, and Thailand (Chen et al., 2009); 1 species in Nepal (Rajbhandari and Rai, 2017), 1 species in Suspa-Kshamawoti.

Luisia tristis (G. Forst.) Hook. f., Fl. Brit. India $6: 25$ (1890).

Epidendrum triste G. Forst.

Habit : Epiphyte, flowers greenish-yellow, 2-4 flowered, lip oblong.

Flowering : Mar-Aug. Exsiccatae : Karki S. 0047 (TUCH)

Altitude : $1,741 \mathrm{~m}$

Habitat : Epiphytic on tree trunks

Host species : Fraxinus floribunda and Schima wallichii

OBERONIA Lindl.

Around 150-200 species, centered in tropical $\mathrm{S}$ and SE Asia but extending to tropical Africa, Madagascar, the Mascarene is lands, the Philippines, New Guinea, NE Australia, and the SW Pacific is lands across to Tahiti (Chen et al., 2009); 19 taxa in Nepal (Rajbhandari and Rai, 
2017), 3 species in Suspa-Kshamawoti.

Oberonia caulescens Lindl., Fol. Orchid. Oberonia $2: 7$, no. 39 (1859)

Malaxis caulescens (Lindl. ) Rchb. f.

Habit : Epiphyte, distichous, falcate leaves.

Flowering : Jun-Jul. Exsiccatae : Karki S. 0069 (TUCH)

Altitude : 2,000-2,200 m

Habitat : Epiphytic on tree trunks

Host species : Buddleja asiatica and Daphniphyllum himalense

Oberoniafalcate King \&Pantl., J. Asiat. Soc. Bengal, Pt. 2, Nat. Hist. 64 (2) : 329 (1895).

Oberonia caudata King \&Pantl.

Habit : Epiphyte, densely flowered, falcate leaves.

Flowering : Jun-Jul. Exsiccatae : Karki S. 0048 (TUCH)

Altitude : 1,700-2,200 m

Habitat : Epiphytic on medium-sized tree trunks

Host species : Buddleja asiatica, Daphniphyllum himalense, and Prunus cerasoides

Oberonia pachyrachis Rchb. f. ex Hook. f., Fl. Brit. India 5 : 681 (1888). Fig. 3D

Oberonia umbraticola Rolfe.

Habit : Epiphyte, flowers pale brown, small many-flowered.

Flowering : Nov-Mar. Exsiccatae : Karki S. 0049 (TUCH)

Altitude : 1,700-2,115 m

Habitat : Epiphytic on tree trunks

Host species : Alnus nepalensis, Schima wallichii, Prunus cerasoides and Fraxinus floribunda

ODONTOCHILUS Blume.

About 40 species : N India and the Himalayas, through SE Asia, as far north as Japan, east to the SW Pacific is lands (Chen et al., 2009); 3 species in Nepal (Raskoti and Kurzweil, 2015), 1 species in Suspa-Kshamawoti.

Odontochilus lanceolatus (Lindl. ) B1., Coll. Orchid. 80 (1859). Fig. 4B

Anoectochilus lanceolatus Lindl.

Habit : Terrestrial, flower yellow, lip golden yellow.

Flowering : Jun-Sep. Exsiccatae : Karki S. 0050 (TUCH)

Altitude : 1,700-2,115 m

Habitat : Terrestrial in humus-rich soil.

OTOCHILUS Lindl.

Around Four species : Bhutan, China, NE India, Myanmar, Nepal, Thailand, and Indochina (Chen et al., 2009); 4 species in Nepal (Rajbhandari and Rai, 2017), 2 species in Suspa-Kshamawoti.
Otochilus lancilabius Seidenf., Bot. Tidsskr. 71 :

13. T. 11 (1976).

Otochilus albus var. lancilabius (Seidenf.)

Pradhan

Habit : Epiphyte, flowers white, small manyflowered.

Flowering : Oct-Nov. Exsiccatae : Karki S. 0051

(TUCH)

Altitude : $2,115 \mathrm{~m}$

Habitat : Epiphytic on tree trunks

Host species : Daphniphyllum himalense

Otochilus porrectus Lindl., Gen. Sp. Orchid. Pl. : 36 (1830). Fig. 3E

Otochilus latifolius Griff.

Habit : Epiphyte, flowers white, small manyflowered, lip 3 lobed.

Flowering : Oct-Dec. Exsiccatae : Karki S. 0052

(TUCH)

Altitude : $1,870-2,115 \mathrm{~m}$

Habitat : Epiphytic on tree trunks

Host species : Schima wallichii and Daphniphyllum himalense

PANISEA (Lindl. ) Steud.

About 7 species distributed in Bhutan, Cambodia, China, North East India, Laos, Myanmar, Nepal, Thailand, Vietnam (Chen et al., 2009); 3 species in Nepal (Rajbhandari and Rai, 2017), 2 species in Suspa-Kshamawoti.

Panisea demissa (D. Don) Pfitz. In Engler, Pfl. -reich IV. 50, I1B-7, Ht. 32 : 141, t. 49 (1907).

Dendrobium demissum D. Don.

Habit : Epiphyte, flowers white, 5-8 flowered, lip sigmoid shaped.

Flowering : Oct-Jan. Exsiccatae : Karki S. 0053 (TUCH)

Altitude : 2,000-2,300 m

Habitat : Epiphytic on tree trunks

Host species : Daphniphyllum himalense and Symplocos sp.

Panisea panchaseensis Subedi, Nord. J. Bot. 29 (3) : 361 (2011). Fig. 3F

Habit : Epiphyte, flowers white, 1-3 flowered, lip tip acute.

Flowering : Oct-Jan. Exsiccatae : Karki S. 0054

(TUCH)

Altitude : 2,100-2,500 m

Habitat : Epiphytic on tree trunks

Host species : Daphniphyllum himalense and Quercus semecarpifolia

PERISTYLUS B1.

About 70 species distributed in E, S, and SE Asia to New Guinea, NE Australia, and the SW Pacific Islands (Chen et al., 2009); 11 species in Nepal 
(Rajbhandari and Rai, 2017), 1 species in SuspaKshamawoti.

Peristylus aristatus Lindl., Gen. Sp. Orchid. P1. : 300 (1835).

Habenaria aristata (Lindl. ) Hook. f.

Habit : Terrestrial, flowers green, many-flowered, lip longer than sepal and petals.

Flowering : Aug-Sep. Exsiccatae : Karki S. 0055 (TUCH)

Altitude : 2,300-2,500 m

Habitat : Terrestrial on humid and humid slopes PHALAENOPSIS B1.

About 46 species distributed in India, South East Asia,Indonesia, Philippines and North Australia (Chen et al., 2009); 3 species in Nepal (Rajbhandari and Rai, 2017), 1 species in SuspaKshamawoti.

Phalaenopsis taenialis (Lindl. ) Christenson \& Pradhan., Indian Orchid J. 1 : 154 (1985). Fig. 3G Aerides taenialis Lindl.

Kingidium taeniale (Lindl. ) P. F. Hunt.

Habit : Epiphyte, flowers pale pink, lip rosepurple, 1-2 flowered, lip 3 lobed.

Flowering : Apr-Jun. Exsiccatae : Karki S. 0056 (TUCH)

Altitude : 1,700-2,300 m

Habitat : Epiphytic on tree trunks

Host species : Schima wallichii, Alnus nepalensis PHOLIDOTA Lindl. ex Hook.

About 30 species distributed in the main 1 and SE Asia, Australia, New Guinea and Pacific Islands (Chen et al., 2009); 5 species in Nepal (Rajbhandari and Rai, 2017), 1 species in SuspaKshamawoti.

Pholidota pallida Lindl. in Edwards's Bot. Reg. 21 : sub t. 1777 (1835).

Coelogyne calceata Rchb. f.

Habit : Epiphyte, flowers white, many-flowered. Flowering : Jun-Jul. Exsiccatae : Karki S. 0057 (TUCH)

Altitude : 1,700-1,800 m

Habitat : Epiphytic on tree trunks

Host species : Buddleja asiatica and Schima wallichii

PINALIA Lindl.

About 160 species distributed from NW Himalayas and NE India to Myanmar, S China, Vietnam, Laos, Thailand, the Malay Archipelago, NE Australia, and the Pacific is lands (Chen et al., 2009); 7 species in Nepal (Rajbhandari and Rai, 2017), 1 species in Suspa-Kshamawoti.

Pinalia spicata (Lindl. ) Kuntze., Fl. China. 25 : 354 (2009).
Eria spicata (D. Don) H and . -Mazz.

Habit : Epiphyte, flowers white, lip apex yellow, many-flowered.

Flowering : Nov-Feb. Exsiccatae : Karki S. 0058 (TUCH)

Altitude : 2,135-2,200 m

Habitat : Epiphytic on tree trunks

Host species : Daphniphyllum himalense and Symplocos sp.

PLEIONE D. Don

About 25 species distributed throughout Nepal, across $\mathrm{C}, \mathrm{S}$, and $\mathrm{E}$ China and Bhutan, south to Laos, Myanmar, Thailand, and Vietnam (Chen et al., 2009); 5 species in Nepal (Rajbhandari and Rai, 2017), 2 species in Suspa-Kshamawoti.

Pleione humilis (Sm. ) D. Don, Prodr. Fl. Nepal. : 37 (1825). Fig. $3 \mathrm{H}$

Coelogyne humilis (Sm. ) Lindl.

Habit : Epiphyte, flowers white, lip white, spotted with crimson or yellow-brown.

Flowering : Feb-Mar. Exsiccatae : Karki S. 0059

(TUCH)

Altitude : 2,135-2,500 m

Habitat : Epiphytic on tree trunks

Host species : Quercus semecarpifolia, Daphniphyllum himalense, and Symplocos sp.

Pleione praecox (Sm. ) D. Don, Prodr. Fl. Nepal. : 37 (1825).

Coelogyne praecox (Sm. ) Lindl.

Habit : Epiphyte, flowers pink with yellow callus, lip fimbriate.

Flowering : Sep-Nov. Exsiccatae : Karki S. 0060 (TUCH)

Altitude : 1,800-2,500 m

Habitat : Epiphytic on tree trunks

Host species : Daphniphyllum himalense, Schima wallichii and Symplocos sp.

PORPAX Lindl.

About 11 species : main 1 and Asia, from India through Thailand and Indochina to Peninsular Malaysia (Chen et al., 2008); 2 species in Nepal (Rajbhandari and Rai, 2017), 1 species in SuspaKshamawoti.

Porpax elwesii (Rchb. f. ) Rolfe, Orchid. Rev. 16 : 8 (1908).

Eria elwesii Rchb. f.

Habit : Epiphyte or lithophyte, flowers dark red or chocolate color, one flowered.

Flowering : Apr-Aug. Exsiccatae : Karki S. 0061 (TUCH)

Altitude : 1,700-1,920 m

Habitat : Epiphytic or lithophyte

Host species : Schima wallichii 


\section{RHYNCHOSTYLIS B1.}

About 4 species distributed in India, Srilanka, Myanmar, South East Asia, Malaysia, Philippines and Indonesia (Chen et al., 2009); 1 species in Nepal (Rajbhandari and Rai, 2017), 1 species in Suspa-Kshamawoti.

Rhynchostylis retusa (L. ) B1., Bijdr. Fl. Nederl. Ind. 7 : 286, t. 49 (1825).

Epidendrum retusum L.

Habit : Epiphyte, flowers purplish pink, lip apex and spur white.

Flowering : Jun-Jul. Exsiccatae : Karki S. 0062 (TUCH)

Altitude : $1,750 \mathrm{~m}$

Habitat : Epiphytic on tree trunks

Host species : Alnus nepalensis and Ficus sp.

\section{SATYRIUM Lw.}

About 90 species distributed mainly in S Africa, with a few species also found in S Asia (Chen et al., 2009); 1 species and 1 variety in Nepal (Rajbhandari and Rai, 2017), 1 species in SuspaKshamawoti.

Satyrium nepalense D. Don, Prodr. Fl. Nepal. 26 (1825).

Satyrium albiflorum A. Rich.

Habit : Terrestrial, flowers whitish pink or pale purple, floral bract reflexed. Flowering : Jul-Nov. Exsiccatae : Karki S. 0063 (TUCH)

Altitude : 2000-2500 m

Habitat : Terrestrial on moist areas like grass lands.

SPIRANTHES Rich.

About 50 species distributed in North America, Africa, Asia, Australia, Central, and South America, and Europe (Chen et al., 2009); 2 species in Nepal (Rajbhandari and Rai, 2017), 2 species in Suspa-Kshamawoti.

Spiranthes sinensis (Pers. ) Ames, Orchid. $2: 53$ (1908). Fig. 4E

Neottia sinensis Pers.

Habit : Terrestrial, flowers pink, lip white, manyflowered.

Flowering : Jul-Aug. Exsiccatae : Karki S. 0064 (TUCH)

Altitude : 1,900-2,500 m

Habitat : Terrestrial on open grassl and

Spiranthes spiralis (L. ) Chevall., Fl. Gen. Env. Paris 2 : 330 (1827).

Ophrys spiralis L.

Habit : Terrestrial, flowers white, lip white, many-flowered.

Flowering : Apr-Jun. Exsiccatae : Karki S. 0065 (TUCH)
Altitude : $1,900-2,100 \mathrm{~m}$

Habitat : Terrestrial on moist areas, wetland UNCIFERA Lindl.

About six species distributed in Tropical Himalayan regions to Indochina and Thailand (Chen et al., 2009); 2 species in Nepal (Rajbhandari and Rai, 2017), 1 species in SuspaKshamawoti.

Uncifera acuminata Lindl., J. Linn. Soc. Bot. 3 : 40 (1859).

Saccolabium acuminatum (Lindl. ) Hook. f.

Habit : Epiphyte, flowers yellow, many-flowered.

Flowering : Apr-Jun. Exsiccatae : Karki S. 0066 (TUCH)

Altitude : 1,670 m

Habitat : Epiphyte on tree trunks

Host species : Eurya acuminata and Schima wallichii

VANDA Jones ex R. Br.

About 40 species distributed in tropical Asia to New Guinea and Australia (Chen et al., 2009); 7 species in Nepal (Rajbhandari and Rai, 2017; Raskoti and Ale, 2019), 1 species in SuspaKshamawoti.

Vanda cristata Lindl. Gen. Sp. Orchid. Pl. 216 (1833). Fig. 3I

Trudelia cristata (Wall. ex Lindl. ) Senghas

Habit : Epiphyte, flowers yellowish-green, lip golden yellow to white, two-lobed.

Flowering : May. Exsiccatae : Karki S. 0067 (TUCH)

Altitude : $1,670-2,200 \mathrm{~m}$

Habitat : Epiphyte on tree trunks

Host species : Prunus cerasoides, Schima wallichii, Alnus nepalensis, Euphorbia royelena, Buddleja asiatica and Ficus sp.

\section{VANDOPSIS Pfitz.}

About five species distributed in India, China, main 1 and SE Asia, the Philippines, the Malay Archipelago to New Guinea (Chen et al., 2009); 1 species in Nepal (Rajbhandari and Rai, 2017), 1 species in Suspa-Kshamawoti.

Vandopsis undulata (Lindl. ) J. J. Sm., Natuurk. Tijdschr. Ned. -Indio 72 : 77 (1912).

Vanda undulata Lindl.

Habit : Epiphyte, flowers white, fragrant, lip yellow to white.

Flowering : May-Jun. Exsiccatae : Karki S. 0068 (TUCH)

Altitude : $1,670-2,300 \mathrm{~m}$

Habitat : Epiphyte on tree trunks

Host species : Daphniphyllum himalense, Quercus semecarpifolia and Schima wallichii 